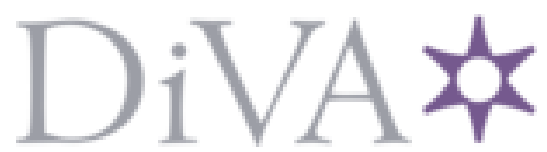

http://www.diva-portal.org

This is the published version of a chapter published in Trends in Iranian and Persian linguistics.

Citation for the original published chapter:

Jahani, C. (2018)

To bring the distant near: On deixis in Iranian oral literature

In: Alireza Korangy and Corey Miller (ed.), Trends in Iranian and Persian linguistics

(pp. 309-338). Berlin and Boston: Mouton de Gruyter

Trends in Linguistics

https://doi.org/10.1515/9783110455793-017

N.B. When citing this work, cite the original published chapter.

Permanent link to this version:

http://urn.kb.se/resolve?urn=urn:nbn:se:uu:diva-341781 
(2)

\section{Trends in Iranian and Persian Linguistics}

Edited by Alireza Korangy Corey Miller 
ISBN 978-3-11-045346-1

e-ISBN (PDF) 978-3-11-045579-3

e-ISBN (EPUB) 978-3-11-045359-1

ISSN 1861-4302

\section{Library of Congress Cataloging-in-Publication Data}

A CIP catalog record for this book has been applied for at the Library of Congress.

Bibliographic information published by the Deutsche Nationalbibliothek

The Deutsche Nationalbibliothek lists this publication in the Deutsche Nationalbibliografie; detailed bibliographic data are available on the Internet at http://dnb.dnb.de.

(C) 2018 Walter de Gruyter GmbH, Berlin/Boston

Typesetting: RoyalStandard, Hong Kong

Printing and binding: CPI books $\mathrm{GmbH}$, Leck

(2) Printed on acid-free paper

Printed in Germany

www.degruyter.com 


\title{
16 To bring the distant near: On deixis in Iranian oral literature
}

\begin{abstract}
The purpose of this article is to study oral narratives in a number of Iranian languages with a particular focus on how the audience is brought inside the framework of the story. The oral narratives selected for this study are traditional folktales and legends in Koroshi Balochi, Sistani Balochi, Vafsi, and Gorani.

Deictic devices locate an event and its participants in time and space and cannot be fully interpreted without reference to the context. They also bring coherence to the narrative. A deictic center is a point to which the deictic element is anchored. Deixis can be absolute, i.e., place the deictic center at the location and moment of utterance, but the speaker does not necessarily need to adopt his or her own time and location as the deictic center. It is also possible to detach the deictic center completely from not only the temporal and locational setting of the speech, but also from the real world, and to place it at a time and place that never existed or will exist inside an imaginary story (deictic shift).

The four linguistic variants in this study show interesting variation when it comes to deictic shift. It is more common for spatial deixis to be shifted to the story than for tense to be anchored in the story. Koroshi Balochi, Sistani Balochi, and Vafsi present almost total spatial deictic shift, whereas in Gorani the deixis is occasionally moved outside the story. Gorani is the language that has the strongest tense anchoring inside the narrative, with almost exclusive use of the non-past tense. At the other extreme we find Sistani Balochi, which has no tense anchoring in the narrative (only past tense verb forms). Koroshi Balochi uses non-past tense for events in the story line and Vafsi changes between using non-past and past tense.
\end{abstract}

Keywords: oral literature, deixis, deictic shift, Balochi, Vafsi, Gorani

\section{Introduction}

The purpose of this article is to study oral narratives in a number of Iranian languages with a particular focus on how deictic devices bring these stories close to the audience in space and time, or rather perhaps how the audience is brought

Carina Jahani, Uppsala University

DOI 10.1515/9783110455793-017 
inside the framework of the story. The oral narratives selected for this study are traditional folktales and legends.

Nyberg (2004: 25) stresses the entertaining rather than moralizing function of oral narratives. Segal (1995: 62) finds that "narrative allows us to vicariously experience phenomena that would be too dangerous or costly to experience directly" and points out that its popularity is obvious since it is "emotionally involving, structurally appealing, and educational”. Like with soap operas of the TV age, it is important to keep the audience's attention, and various linguistic and extralinguistic means have been observed in Iranian oral narratives for this very purpose.

In his discussion of genres in Persian literature, Utas (2008: 229) describes the language of both oral and written literature as "normalized, conventionalized and consciously shaped to be remembered" and thereby fundamentally different from spoken language. In this he opposes Ong (1982: 11-14), who discards the concept of oral literature. Ong believes that only written words are of a lasting character, and that "oral tradition has no such residue or deposit".

The language of oral narratives described in this study is thus, according to Utas, to be regarded as a consciously shaped literary language, albeit not a written language, and by no means an ad hoc creation on each occasion of storytelling. It must therefore be assumed that such a language has its own rules, which are rather stable and possible to describe.

This study will investigate how different Iranian languages employ deictic strategies to bring the audience into the story, whether these strategies are employed in all the linguistic varieties under study, and if the strategies are similar or vary considerably from language to language. The focus here will be to investigate deictic pronouns and determiners as well as tense use in four different Iranian varieties, namely Koroshi Balochi, Sistani Balochi, Vafsi, and Gorani. For all these varieties, there are publications with oral tales in transcription and translation into English. For three of the variants, one or more of the texts is fully glossed. There are also grammatical sketches and word lists available, which makes it possible to analyze the texts even when they are not fully glossed.

The narratives selected consist of:

- four tales in Koroshi Balochi with full glossing and English translation published by Nourzaei et al. (2015: 123-209);

- nine tales in Sistani Balochi with full glossing and translation into English published by Barjasteh Delforooz (2010: 286-325, 336-391);

- seven tales in Vafsi with English translation published by Stilo (2004: 26-29, 32-57, 104-123);

- three tales in Gorani, all with English translation and one with full glossing published by Mahmoudveysi et al. (2012: 63-103). 
The selected variants are all representatives of northwestern Iranian languages, although a strict division of western Iranian languages into a northwestern and a southwestern group has lately been questioned by Paul (2003: 71) and Korn (2005: 329-330).

Koroshi Balochi is spoken by scattered populations throughout southern Iran, "from Hormozgan all the way to Khuzestan, and onto the Iranian plateau. [...] Three areas with significant concentrations of Korosh are Bandar Abbas, around Shiraz, and across the southern part of Fars Province" (Nourzaei et al. 2015: 21). Although Koroshi shares many features with Southern Balochi, ${ }^{1}$ it must be regarded as a distinct subgroup of Balochi with its own dialect division into Northern Koroshi and Southern Koroshi (Nourzaei et al. 2015: 25). The fieldwork for the monograph in which the tales were published was carried out between 2009 and 2014 by Maryam Nourzaei in and around Shiraz in northwestern Fars Province, Iran, and represents northern Koroshi (Nourzaei et al. 2015: 17-18).

Sistani Balochi, which is a variant of Western Balochi, is spoken in Iranian Sistan as well as in adjacent parts of Afghanistan and in scattered pockets throughout northeastern Iran. It is also very similar to the Balochi dialect spoken in Turkmenistan. The fieldwork for the monograph in which the tales were published was carried out between 2000 and 2005 by Barjasteh Delforooz and comprised speakers from both the Iranian and the Afghan part of Sistan (Barjasteh Delforooz 2010: 26).

Vafsi is, according to Stilo (2004: 1), "spoken in four villages in west central Iran: Vafs, Chehreqān, Gurchān, and Fark”. These villages are situated southwest of Tehran, between Saveh and Hamedan in Markazi Province, Iran. The folktales published by Stilo were collected by L. P. Elwell-Sutton in the village of Gurchān in 1958. Stilo himself conducted extensive fieldwork on Vafsi in the 1960s and 1970s. This volume was prepared between 1997 and 2000 (Stilo 2004: vii, 5-10).

Gorani, as used by Mahmoudveysi et al. (2012: 2-4), is a general term for a number of vernaculars spoken in pockets in Kermanshah Province, Iran (an area dominated by Southern Kurdish dialects), as well as in adjacent parts of Iraq. The dialect under study in this monograph, Gawrajūyī, is one of several Gorani variants. Fieldwork for the present monograph was carried out in 2007 and 2008 by Mahmoudveysi in Gawrajūu, "a cluster of four hamlets in the Zimkān river valley” in Kermanshah Province, Iran (Mahmoudveysi et al. 2012: 1).

All the variants under study have a basic split between past and non-past (present-future) tense. They are all pro-drop and have agreement marking by means of person-marking suffixes on the verb in the non-ergative domain

1 For dialect divisions in Balochi, see Jahani and Korn (2009: 636-638). 
(intransitive verbs and transitive verbs in the non-past tense). Vafsi and Sistani Balochi exhibit a type of differential object marking (DOM) that is common in Iranian languages (Haig 2008: 157-158; Stilo 2004: 232; Barjasteh Delforooz 2010: 286-391), but Koroshi Balochi shows interesting divergences from the normal DOM system in Iranian languages (Nourzaei et al. 2015: 35-36). In the variant of Gorani described by Mahmoudveysi et al. (2012) there is no case marking.

In Vafsi, the subject of intransitive verbs (S), the agent of transitive verbs (A) in the non-past system, and the patient $(\mathrm{P})$ of transitive verbs in the past system take the direct case, whereas the $\mathrm{A}$ in the past system and the $\mathrm{P}$ in the non-past system take the oblique case. We thus have a split ergative construction in Vafsi, in line with the common tense-split ergativity found in Iranian languages (Stilo 2004: 232). In Koroshi Balochi, alignment is normally non-ergative, but the enclitic pronouns remain as agreement markers in the past tense of transitive verbs, in contrast with person-marking suffixes found on all intransitive verbs and on transitive verbs in the non-past system (Nourzaei et al. 2015: 83). The same system of two different sets of agreement markers is found in Gorani of Gawraǰū (Mahmoudveysi et al. 2012: 27-28). Sistani Balochi also has non-ergative alignment, and all verbs mainly have the same person-marking suffixes in both the non-past and the past tense (Barjasteh Delforooz 2010: 286-391).

\section{Deixis}

Deictic devices locate an event and its participants in time and space and cannot be fully interpreted without reference to the context. They also bring coherence to the narrative. Anderson and Keenan (1985: 259) define deictic expressions as "those linguistic elements whose interpretation in simple sentences makes essential reference to properties of the extralinguistic context of the utterance in which they occur”. They (Anderson and Keenan 1985: 259) recognize only three major categories of deixis: person deixis, spatial deixis, and temporal deixis. However, Fillmore (1997: 61) adds social deixis ("the social relationships on the part of the participants in the conversation"), and crucially for this article, discourse deixis, which deals with "the choice of lexical or grammatical elements which indicate or otherwise refer to some portion or aspect of the ongoing discourse" (Fillmore 1997: 103).

A deictic center is a point to which the deictic element is anchored. Deixis can be absolute, i.e., place the deictic center at the location and moment of utterance. Lyons (1977: 578-579) finds that the speaker does not necessarily 
need to adopt his or her own time and location as the deictic center, as in e.g., "I am going abroad next week". It is alternatively possible to adopt the spatiotemporal setting of, e.g., an addressee, as in "look left", to be understood as left of the addressee. Lyons calls this phenomenon deictic projection. ${ }^{2}$

It is also possible for the deictic center not to be grounded in the actual speech situation at all, which in the case of oral literature would be when the story is actually told. In this case, deictic projection is realized as a movement of the deictic center "from the speaker to an imaginary observer in the story world" (Diessel 1999: 95). It is thus possible to detach the deictic center completely from not only the temporal and locational setting of the speech, but also from the real world, and to place it at a time and place that never existed or will exist, inside an imaginary story. Segal (1995: 14-15) calls this "deictic shift" and finds that:

this act of imagination was commented on over 2,000 years ago by Aristotle in his Poetics. He pointed out that poetry (tragedy, comedy, epic) was a mimetic art; its primary mode was to represent actions. The Greek word, mimesis, refers to imitation, or representation, or experience of that which is not literally present. [...] The deictic shift approach is consistent with phenomenological experience. When reading fictional text, most readers feel they are in the middle of the story, and they eagerly or hesitantly wait to see what will happen next. Readers get inside of stories and vicariously experience them. They feel happy when good things occur, worry when characters are in danger, feel sad, and may even cry, when misfortune strikes. While in the middle of a story, they are likely to use past tense verbs for events that have already occurred, and future tense for those that have not.

Deictic shift is applicable to written as well as oral narration. In oral narratives it is common for the narrator to first provide an introduction outside the frame of the story and with the deictic center in the actual speech situation (Zubin and Hewitt 1995: 131) by an introduction such as "Once upon a time there was ...”. Then the narrator has the option of moving the deictic center into the story by "decoupling the linguistic marking of deixis from the speech situation, and reorienting it to the major characters, the locations, and a fictive present time of the story world itself" (Zubin and Hewitt 1995: 131).

In the following two sections, spatial, discourse, and temporal deixis in the selected corpus will be discussed in detail, with a particular emphasis on demonstrating how spatial and temporal deixis is anchored inside the story rather than in the real world.

2 Levinsohn (2015: 144-145) provides a set of questions to determine whether and to what extent a particular language allows deictic projection. 


\section{Spatial and discourse deixis in the analyzed corpus}

In this section, spatial and discourse deixis in the present corpus will be analyzed. All the variants under study have a two-way contrast, proximal versus distal deixis for demonstrative determiners ${ }^{3}$ and pronouns. For deictic spatial adverbs, Sistani Balochi (Barjasteh Delforooz 2010: 138) and possibly also Koroshi Balochi (see n. 5), exhibit a three-way deixis with the locational adverbs "here, there1, there2".

It should be noted that the transcription of language data in the sections below follows that of the works in which the stories were originally published. I have, however, removed marking of stress in those texts that had stress marking, since stress marking was found in only two of the corpuses. The translation mainly follows that of the original works, but minor adjustments have sometimes been made, particularly to demonstrate overtly the meaning of the deictic items.

Direct speech has by default its deictic anchoring inside the story and is therefore of less interest in the discussion of deictic shift. Even so, there are interesting conclusions to be drawn from the use of deictic devices in direct speech as well, and they are therefore marked and discussed in the examples in sections 3.1-3.4 below. All forms that contain a deictic element are marked in bold and provided in brackets in the original language.

\subsection{Koroshi Balochi}

Four Koroshi Balochi stories have been investigated. The findings in two of these will be discussed below. The other two stories show a similar picture. Demonstrative determiners and spatial adverbs found in Koroshi Balochi are given in Table 1 and demonstrative pronouns are given in Table 2 (see also Nourzaei et al. 2015: 49-50). ${ }^{4}$

3 In fact, the contrast involving determiners is a three-way one between the absence of a determiner (e.g., "lion") and the presence of a proximal or a distal determiner (e.g., "this lion", "that lion").

4 Most of these forms can add an emphatic ham before the actual demonstrative (e.g., hame 'this very', hamā 'that very', hamēšì 'of this very', hamēšān 'these very', hamīdān 'right here'). 
Table 1: Demonstrative determiners and spatial adverbs in Koroshi Balochi

\begin{tabular}{|c|c|c|}
\hline & Proximal & Distal \\
\hline Determiner & $\bar{e}, \bar{i}$ 'this' & $\bar{a}$ 'that' \\
\hline Adverb & $\begin{array}{l}\bar{i} \eta(r), \bar{i} \eta \bar{a}, \bar{e} d \bar{a}(n), \text { edā(n), eda, ìdān 'here' } \\
\bar{e} d a \bar{n} \bar{a} k \bar{o}, \bar{e} d \bar{a} n a k \bar{o}, \bar{i} d \bar{a} n \bar{k} k \bar{o}, \bar{i} d a \bar{n} a k \bar{o} \\
\text { 'right here' }\end{array}$ & $\begin{array}{l}\bar{a} \eta a, \bar{a} d \bar{a}, \text { odān, ōdān }{ }^{5} \text { 'there' } \\
\text { ódānākō 'right there' }\end{array}$ \\
\hline
\end{tabular}

Table 2: Demonstrative pronouns in Koroshi Balochi

\begin{tabular}{|c|c|c|c|c|c|}
\hline & & Nominative & Oblique & Genitive & Object \\
\hline \multirow{2}{*}{ Proximal } & $S G$ & $\bar{l}, \bar{e}, \bar{e} \check{S}$ & \multicolumn{3}{|c|}{ ēšî, išš, eši } \\
\hline & $\mathrm{PL}$ & \multicolumn{2}{|c|}{ ēšān, išān, ešān, šān } & ēšānī, ǐšānī, ešānī & 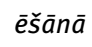 \\
\hline \multirow{2}{*}{ Distal } & $S G$ & $\bar{a}$ & \multicolumn{3}{|c|}{$\bar{a} h \bar{i}, \bar{a} \bar{l}, \bar{a} s ̌ \bar{l}$} \\
\hline & $\mathrm{PL}$ & \multicolumn{2}{|c|}{$\bar{a} s ̌ a ̄ n$} & $\bar{a}$ šānì & $\bar{a} \check{s} a \bar{n} \bar{a}$ \\
\hline
\end{tabular}

I begin with a detailed investigation of spatial deixis in the story Goli and Ahmad, told by an experienced storyteller, Alamdar Samsanian, and published in Nourzaei et al. (2015: 130-146). In this story, the first four discourse units (see Nourzaei et al. 2015: 20) have the character of an introduction with the deictic center outside the story:

\footnotetext{
Well, once upon a time ... Well, a woman, there was a woman, her name was Goli. [She] ${ }^{6}$ was actually very bad. [She] was actually very bad. [She] was giving her husband a hard time, you know.
}

5 There is not enough data to determine if odān/ōdān and $\bar{a} d \bar{a}$ show two different degrees of distal deixis in this corpus, as they do in Sistani Balochi (see Barjasteh Delforooz 2010: 138).

6 Personal and demonstratives pronouns, as well as the adverb "there", that are not found in the original text are given in square brackets. This also applies when there is an enclitic pronoun functioning as agent clitic in the ergative domain. However, non-canonical (dative) subjects expressed by enclitic pronouns are given without brackets (e.g., "to me there is a child", meaning "I have a child"). In order to make the text easier to read, other words that have been supplied in the English translation are placed in square brackets only if they occur in a deictic expression. No brackets are provided in summarized text sections. Other additions are not marked here. 
Then there is a tense change to the non-past tense ${ }^{7}$ (see also section 3), and the actual story starts. The next five discourse units take place on the very same day.

So, one day her husband says, "Hey, Goli, all these people (ì hāmmo mardom) are going to pick green herbs here [and] there (āna ìna), come on, let the two of us go, too". [She] says, "Very well, let's go". [They] go out into this wilderness (hamī sahrā), you know, [they] pick green herbs, like this ( $\bar{a} \eta a$ in $a$ ). The man goes and finds a well. The man finds a well. [He] says, "Hey, my wife, look into this well ( $\bar{e} \check{c} \bar{a} h \bar{a})$, what is this $(\bar{e})$ [thing] that shines?" The woman comes, sir, to look into the well. The man pushes her in such a way that she (lit. 'the woman') falls into the well.

In this section, there are three proximal demonstrative determiners, one proximal demonstrative pronoun, and two occurrences of the phrase āya inga 'here and there, like this' (lit. 'there here'), which consists of both a proximal and a distal spatial deictic adverb. Three of the demonstratives ${ }^{8}$ occur in direct speech, and one in the narration. The deictic center for the reported speech is, of course, the location of the speaker, but the deictic center for the narration is now inside the story, something that can be seen in the use of a proximal deictic device outside direct speech (i.e., this wilderness). Here we thus see that a deictic shift has taken place. In the next five discourse units the story evolves in the following way:

[She] falls into the well and [he] comes back home. After four, five days her husband says, “I shouldn't have done like this, I shouldn’t have thrown this one (ěši) into the well. [She] was my wife". Anyhow, [he] becomes troubled, takes a rope and goes. [He] takes [it] and goes until [he] arrives at the well. [He] throws the rope into the well and says, "Hey, Goli, if you are alive, take hold of the rope, so that I can pull you up". Well, [he] pulls up the rope, like this (hamitaw). [He] sees the rope is heavy.

Here, there is only one proximal demonstrative pronoun in direct speech, and one adverb with proximal deixis in the narration. Although the husband is now rather far away from the well where he threw his wife, he is still able to use proximal deixis when he is talking about her. It seems that proximal deixis is used here to make a minor participant (in this case Goli) temporarily salient, i.e., the current center of attention (Levinsohn 2015: 139-140). In the next eight discourse units the story takes an unexpected turn.

7 Note that in Nourzaei et al. (2015) the story is translated into the past tense, since this is the default tense for narration of past events in English. Here, on the contrary, the translation reflects the actual tense form of the verb. The demonstratives are also translated with the corresponding English proximal or distal demonstrative to reflect the original structure.

8 The phrase âna in $a$ is not counted here. 
[He] pulls and pulls until [he] suddenly sees that a dragon came up. A dragon came up. [He] becomes panicky and wants to let go of the rope, but the dragon says, “Don't let go of the rope, I will give you whatever you want". The man says, "Fine, can you get the king's daughter for me?" The dragon says, "Yes, I will get [her] for you". So then this one (e) (i.e., the dragon) says, "Very well, tonight I will go and wrap myself around the neck of the king's daughter. Then, no matter who comes (lit. 'came'), I will not unwrap myself except for you. When you come (lit. 'came'), I will unwrap myself. Then say, 'Oh king, if you are going to marry off your daughter, give [her] to me, and I will open up this dragon ( $\bar{e} a z ̌ d a h \bar{a})^{\prime}$ '”. Well, in the evening the dragon goes and wraps itself around the neck of the king's daughter.

There are two proximal demonstratives in this section: one is a pronoun in a narrative section, indicating that the dragon, rather than the man, becomes the center of attention, and the other is a determiner in direct speech. The next five discourse units take place the next morning.

In the morning, when [they] get up, [they] see that the dragon is indeed wrapped around the neck of the king's daughter. Even though [they] bring all kinds of wise men, all kinds from here [and] there (āna inar), [it] doesn’t unwrap itself. [They] say, "So, is there anyone left?" Someone says, "There is one person, a poor fellow who is called Ahmad, that one $(\bar{a})$ is left”. The king says, "Well, go and bring that one (hamāhì), too!"

Here, in addition to the phrase "here and there" already discussed above, there are two distal demonstratives, both in direct speech. It seems that there is a need to establish a contrast between the people at the deictic center (the court) and Ahmad, who is in another place, so therefore the distal deictic is used. There is thus both a spatial and a mental distance between those who are speaking and Ahmad.

The next four units tell how Ahmad succeeds in becoming the king's son-inlaw.

[They] go and when [they] bring Ahmad, Ahmad says to the king, "O king, if you are going to marry off this your daughter ( $\bar{e}$ janekat), give [her] to me, so that I can unwrap this dragon $(\bar{e} a \check{z} d a h \bar{a})$ from her neck". Well, then the king has no choice. [He] says, "Very well, I will marry [her] off, I will give [her] to you". Anyway, [he] marries her off, [he] gives her to Ahmad and then Ahmad goes and whispers something in the dragon's ear and the dragon goes away.

There are two proximal demonstrative determiners here; both are used in direct speech and for entities that are close to the speaker.

In the following six units there is yet another development in the story, when the dragon wraps itself around the neck of another king's daughter. 
When (lit. 'here that' èdān ke) the dragon unwraps itself to go, well, it says, “Ahmad, I am leaving right away (lit. '[I] went') but if [I] ever wrap myself around anybody's neck, [you] should not come, you know! If [you] do, then [I] will get angry and eat you”. [He] says, "Well, no, I won't come". Anyhow, the dragon goes its way. [It] goes its way, [it] goes to another town and wraps itself around the neck of another king's daughter. Even though [they] bring all the wise men from here [and] there (āna ìnar), sir, [it] doesn't unwrap itself. [It] doesn't unwrap itself until people say, "In such-and-such a town there is a person called Ahmad, [he] is the king's son-in-law. That one $(\bar{a})$ can unwrap it".

In this passage there is one distal demonstrative pronoun in direct speech. This distal demonstrative indicates a long distance from the present deictic center, i.e., Ahmad who is in another town. In addition, it brings out the contrast between the wise men who failed and Ahmad, who is assumed to be able to solve the problem. There is also one proximal spatial adverb in the conjunction that denotes a temporal relation between the subordinate and the main clause at the beginning of the passage, and one occurrence of the phrase "here and there" discussed above.

In the following six units, Ahmad is approached to solve the problem. He is hesitant at first, because of the dragon's previous threat. There are no demonstratives in this passage.

So [they] go to find Ahmad. But Ahmad, who is dead scared of the dragon, is not coming. Anyway, the king says, "No, you must go. [It] is improper", and such things. [He] sends him away. Ahmad is coming but [he] is worried, you know, and says to himself, "What should I do? The dragon will eat me", things like that. Then, in the middle of the road, suddenly [he] gets an idea. [He] gets an idea about what to say (lit. 'what [I] should say'). [He] says, "Great!" [They] see that Ahmad, who was very worried before, is now laughing and happy. Someone says, "Ahmad, how are you feeling?" [He] says, "Never mind, let's go, I will unwrap the dragon”.

In the following ten units the story is resolved.

[They] go and go and when they arrive here on this side (hami inare) of the court, you know, [they] see that indeed the dragon is wrapped around the neck of the king's daughter. So, these (šân), go closer. When the dragon's eye falls on Ahmad, [it] gets angry. [It] says, "Well, didn’t [I] tell you not to come?!” Ahmad says, "I didn’t come to say 'unwrap yourself' actually. [I] didn't come to say 'come loose, and go!'” The dragon says, "So what do you have to say?" Ahmad says, "I only have a message for you". The dragon says, "What is [it]?" Ahmad says, "Goli has come out of the well and she is looking for you!" Sir, the dragon unwraps itself out of fear, and how [it] is running!

In this final part of the story, there is one proximal spatial adverb, one proximal demonstrative determiner, and one proximal demonstrative pronoun. Again, 
Ahmad and his people arrive close to the palace; they do not pass by it in relation to where they came from. Where Ahmad (the main protagonist) is, the deictic center is there as well.

The final unit is the formal ending, which does not belong to the actual story; in it the deixis has shifted from inside the story back to the actual occasion of the narration, thus the distal demonstrative determiner.

Now, may our enemy experience what Goli did and our friend what that Ahmad (hamā ahmad) did.

In the rest of the material from Koroshi Balochi a similar picture emerges. The longest story in the corpus, entitled The King's Son and published in Nourzaei et al. (2015: 162-209), can be summarized as in Table 3:

Table 3: Deixis in The King's Son

\begin{tabular}{lll}
\hline & Proximal & Distal \\
\hline Determiner & 41 & 8 \\
Pronoun & 26 & 2 \\
Adverb & 13 & 1 \\
\hline
\end{tabular}

There are many examples where proximal deixis is used for objects and persons physically remote from the deictic center, but still at the current center of attention. Unit 12 (Nourzaei et al. 2015: 165) is said about a foal that has not yet been born, but which is the current center of attention due to the magical power it will possess. The previous two units have described how it should be raised, and the following statement is then made:

Then this foal (e korrag) can provide you with whatever you may want.

In unit 112 (Nourzaei et al. 2015: 200), a woman is talking to her husband about her sisters, who are not physically with them, but who are the reason why she is sad, and thus are important in this context. She says, I know that you are not bald, I know who you are, these (ǐšān) are ridiculing me.

Distal demonstratives can create a contrast between two different entities. In units 75-76 (Nourzaei et al. 2015: 188), the six elder sisters, marked with a distal demonstrative, do one thing, and their little sister, marked with a proximal demonstrative, does something else and unexpected, which attracts attention. In fact, they are all at the same location when the action takes place: 
So, those six sisters of hers ( $\bar{a}$ ššs gāhārī), each one of them hits someone, one, for example, hits the vizier's son in the chest. In short, each one hits a rich person, you know. [They] hit some boys, but this youngest girl (ì kassānoēn janek) doesn’t throw her apple.

Two more instances of a distal demonstrative being used to create a contrast between two entities are found. One is in the reported speech of unit 98 (Nourzaei et al. 2015: 195) and the other is in the narration of unit 111 (Nourzaei et al. 2015: 200).

Then [they] say well, these six sons-in-law (ī šiš dūmād) say, "Well, there is [another] one too, he has (lit. 'there is to him') a lame mule, [he] comes afterwards, give him the meat, that one $(\bar{a})$ should bring [it]".

... these six sisters of hers ( $\bar{e}$ ššs gāhārī) keep ridiculing that one ( $\bar{a} \bar{l})$ (i.e., the youngest sister) ...

Distal demonstratives are also found as a reactivating device. In unit 70 (Nourzaei et al. 2015: 186), the two entities that are marked with the distal demonstrative determiner are present at the current deictic center, but they are marked with the distal demonstrative for discourse deictic purposes, i.e., to reactivate a previously mentioned topic without changing the deictic center. The proximal demonstratives in units 69 and 70 ( $\bar{e} / \bar{\imath} b \bar{a} \dot{g} \bar{a}, \bar{l})$ (Nourzaei et al. 2015: 185-186) indicate the current center of attention.

She sees, dear Lord! [There] is a rider on a horse in this garden ( $\bar{\imath} b \bar{a} \dot{g} \bar{a})$, [he] is riding around, it is as if [there] is an angel riding around in this garden $(\bar{e} b \bar{a} \dot{g} \bar{a})$. After a while [he] stops, [he] stops. [She] sees that [he] gets off the horse. [She] goes towards [him] and this one (i) came towards [her] too. [He] pulls that same aforementioned stomach (hamā komaokā) over his head. [She] sees that it is that very bald one (hamā kačal) who works in their garden.

Two distal demonstrative determiners are found in the very last unit of the story, unit 141 (Nourzaei et al. 2015: 209), where the spatial anchoring is no longer located within the story but is at the moment of narration:

Now, may it happen to our friend like to that king's son (čō hamā šāhay bačă) and to our enemy like to those six servants ( $\check{c} \bar{o}$ hamā šǐs nawkarā).

There are three more distal demonstrative determiners in the text, which will be discussed in section 4.1 because they are all connected to temporal adverbs. 


\subsection{Sistani Balochi}

For Sistani Balochi nine stories have been included in this study (Barjasteh Delforooz 2010: 286-325, 336-391). The results for two of them will be presented here. The rest provide a similar picture. The demonstrative determiners and spatial adverbs found in the Sistani Balochi texts in this corpus are presented in Table 4, and the Sistani Balochi demonstrative pronouns in Table 5 (see also Barjasteh Delforooz 2010: 138, 150-151). ${ }^{9}$

Table 4: Demonstrative determiners and spatial adverbs in Sistani Balochi

\begin{tabular}{llll}
\hline & Proximal & Distal 1 & Distal 2 \\
\hline Determiner & $\bar{e}, \bar{l}$ 'this' & $\bar{a}$ 'that' & \\
Adverb & $i d \bar{a}$ 'here' & $\bar{o} d \bar{a}$ 'there' & $\bar{a}(d) d \bar{a}$ 'far away there' \\
\hline
\end{tabular}

Table 5: Demonstrative pronouns in Sistani Balochi

\begin{tabular}{|c|c|c|c|c|c|}
\hline & & Nominative & Oblique & Genitive & Object \\
\hline \multirow{2}{*}{ Proximal } & $S G$ & $\bar{e}, y \bar{e}, \bar{l}, \bar{e} \check{s}$ & \multicolumn{2}{|c|}{$\bar{e} s ̌ \bar{I}, e s ̌ \bar{~}$} & 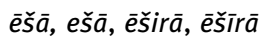 \\
\hline & $\mathrm{PL}$ & $\bar{e}, \bar{i}, \bar{e} s \check{s}$ & ēšāan & ēšānī, ešānī & ēšānā \\
\hline \multirow{2}{*}{ Distal } & $S G$ & $\bar{a}$ & \multicolumn{2}{|c|}{$\bar{a}(y) \bar{i}$} & $\bar{a}(y) \operatorname{ira} a$ \\
\hline & PL & $\bar{a}$ & $\bar{a} w a \bar{n}$ & $\bar{a} w a ̄ n \bar{~}$ & $\bar{a} w a ̄ n a ̄$ \\
\hline
\end{tabular}

One of the Sistani Balochi tales, The Story of the Lion and the Three Bulls, told by the experienced storyteller Paraddin Gorgej (Barjasteh Delforooz 2010: 378-383), is here presented in its entirety. Like those in Koroshi Balochi, the stories in Sistani Balochi exhibit deictic shift, and in the story below proximal deixis is overwhelmingly predominant, to such an extent that nouns are used more frequently with a determiner than without.

Sir, [they] say, there were three cows. All these three cows (i har say gōk) were in unity (lit. 'in one heart'), there was a black one, there was a light brown one, and there was a white one. These $(\bar{e})$ were in unity from that [old] time (ama waxt $\bar{a})$. Wherever [they] grazed no beast of prey had any power against these (ešāni $)$. If there was a lion, if there was a leopard, if there was a wolf, that attacked one [of them], all three attacked [it] and no beast of prey attacked these (ěšanni sarā), because they were of one heart and of one mind. What did a certain lion do? [It] was stalking these (ēšānì), [it] was lying in ambush for these (ěšāni). It said, "Unless I change the mind of each one of these (ěšannā), I won’t

9 These forms can add an emphatic am before the actual demonstrative (e.g., ame 'this very', $a m \bar{a}$ 'that very', amēšì 'of this very', amēšān 'these very', amidā 'right here'). 
be able to eat these ( $\bar{i})$ (lit. 'these won't be eaten')". This lion ( $\bar{e}$ šir $)$ came and lied to these (ēšānā), told these (ēšăn) a lie, "O fellows, you are this kind of [good] friends ( $\bar{e}$ rangēn rapēy), I am your fourth brother. I have seen a pasture in a place. [It] is very green (lit. 'spring'). You ... let's go there (ōdā), I will take you there, you eat that grass (lit. 'spring') $(\bar{a}$ bahārā). I will watch over you”, the lion said. [It] deceived (lit. 'made donkey') these (ēšānā) and took [them]. When [it] took [them], [it] said, "Now I will watch over you on this mound ( $\bar{e}$ dikkayay sarā), you eat this grass ( $\bar{e}$ bahārānā)". [It] passed, that day (lit. 'today') passed and the next day (lit. 'tomorrow') passed, [it] whispered in the light brown cow's ear and in the white one's. [It] said, "O friend, your hair and my hair are the same colour, that black [one] ( $a m \bar{a}$ siyāhēn) is ill-matched (lit. 'unripe') among us. You, don't help [it], I will eat that [one] (āyirā), a lot of grass will remain for you". [It] confused these ones' (ěšān $\bar{l}$ minds and one of the cows said, "Fine". So it seized the black one. Those $(\bar{a})$ didn’t help. When [they] didn’t help, [it] overpowered this (eši) single one. [It] ate this one $(\overline{e s ̌ a})$ up. When [it] ate and finished it ..., when [it] finished this (eša $)$ [it] whispered in the light brown cow's ear and said, "Your hair and mine are the same colour, you, don't help [it], when I eat this $(a m \bar{e})$ white one, all the grass will remain for you. Then I will watch over you here (idā), you can eat!" [It] said, "Fine”. When [it] seized this one (ēširā) too, that one $(\bar{a})$ (i.e., the light brown one) didn't help. The lion ate this one (ēširā) (i.e., the white one) too. When [it] finished this one (ēša $)$ too, [it] said to that one (āyirā), "Now [I] alone am more powerful than you". [It] ate that one (āyirā) too. In this manner ( $\bar{e}$ rangī), with this trick (ē sīyāsat), [it] destroyed these ones (ēšānā).

Proximal deixis must be seen as the default in this story. It is interesting to note that even in the final comment "in this manner, with this trick, it destroyed these ones", where a shift out of the actual story may have been expected, proximal deixis remains. In addition to the proximal deictics, the story provides some interesting examples of distal deixis. The first three, "that $(\bar{a})$ old time", "there $(\bar{o} d \bar{a})$ ", and that grass ( $\bar{a}$ bahārā) can easily be explained as indicating a distant time and a distant place, far from the present deictic center. The following five ones, though, all indicate entities that are present at the deictic center; however, a contrast needs to be established between the cow that is to be eaten and the other $\operatorname{cow}(\mathrm{s})$.

Another story in Sistani Balochi, Xarmizza (Barjasteh Delforooz 2010: 286293) contain the following deictic items (Table 6):

Table 6: Deixis in Xarmizza

\begin{tabular}{lll}
\hline & Proximal & Distal \\
\hline Determiner & 20 & - \\
Pronoun & 30 & 1 \\
Adverb & 1 & 3 \\
\hline
\end{tabular}

As in the previous Sistani Balochi tale, here, too, proximal deixis is completely predominant when compared to distal deixis. This time, however, the proximal 
determiner is used less frequently than the simple noun. ${ }^{10}$ There are several examples of how a proximal deictic determiner or pronoun is used even if the entity referred to is not present at the deictic center, such as when the king in his palace refers to a dragon far away from the palace with proximal deixis (units 14-20, Barjasteh Delforooz 2010: 287). The use of the verb "to bring" clearly shows that the dragon is not present at the palace:

[They] came back. One of them said, "Lord king, [it] is a dragon". The king said, "Oh ... this dragon ( $\bar{e}$ aždiy $\bar{a})$ has something to say, [it] has a petition, who can bring this one's (ēšì) petition to me?”

In another very interesting example, proximal deixis is used to refer to the palace, although the story has now moved from the palace to the mountain, where the dragon obviously lives (units 34-43, Barjasteh Delforooz 2010: 288289). However, the passage starts out with a distal deictic adverb indicating a movement from the former deictic center (the town, where the dragon has come to seek help for a problem) to the new deictic center (the mountain, where the dragon takes the carpenter who has come to help).

The dragon gave the carpenter one hint after another and went onto the mountain. When [he] went there $(\bar{o} d \bar{a})$, good heavens ohhh ... this dragon $(\bar{e}$ aždiy $\bar{a})$ has a mother as well. This one's (ēšì) mother, there are (lit. 'aren't') this [kind of] wild mountain goats (ame kōhay pāčin) with big horns, it has caught one of these (amēšān) and these (amē) its horns have got stuck in the mother's throat and [it] is short of breath, the dragon has come here (idā) and informed the king.

In this example, "has come here (idā)" refers to the previous deictic center, i.e., the town where the previous scene was located, rather than to the mountain, where the hero and the dragon have now gone.

There are a few additional distal demonstratives to account for, apart from the one in the example above "there $(\bar{o} d \bar{a})$ ". Two more occurrences of "there $(\bar{o} d \bar{a})$ " are found in the text, one referring to a place that is not the current deictic center (Barjasteh Delforooz 2010: 287) and one at the very end of the story "the name xarmizza ('melon', lit. 'donkey tasted') remained from there ( $\bar{o} d \bar{a})$ " (Barjasteh Delforooz 2010: 293). The latter occurrence must be seen as an addition to the actual story where the narrator shifts the deictic center from within the story to the moment of narration to account for why this fruit is called what it is even now. The one distal demonstrative pronoun in this text (Barjasteh Delforooz 2010: 289) is found in a context where there is a need to create a contrast between two entities that both are present at the deictic center, namely

10 For example, the noun for "king" occurs once with the proximal determiner and six times with no determiner. 
the carpenter, who rescues the mother dragon and is the participant through whom the story will continue to develop, and the mother dragon herself, who has no further part to play in the story:

This one $(\bar{e})$ (i.e., the carpenter) sawed the wild goat's horns and that one $(\bar{a})$ (i.e. the mother dragon) was rescued.

\subsection{Vafsi}

Seven stories have been investigated for Vafsi. The results from four of them are presented here. The other stories show similar results. The demonstrative determiners and adverbs found in the Vafsi texts are presented in Table 7 and the demonstrative pronouns in Table 8 (see also Stilo 2004: 225, 227).

Table 7: Demonstrative determiners and adverbs in Vafsi

\begin{tabular}{lll}
\hline & Proximal & Distal \\
\hline Determiner & in 'this' & an 'that' \\
Adverb & indi, indiænæ 'here' & andi, andiænæ 'there' \\
& ena 'this way' & ana 'that way' \\
\hline
\end{tabular}

Table 8: Demonstrative pronouns in Vafsi

\begin{tabular}{llll}
\hline & & Nominative & Oblique \\
\hline Proximal & $\mathrm{SG}$ & in & tini, intine, intini \\
& $\mathrm{PL}$ & ine & tinan \\
Distal & $\mathrm{SG}$ & an & tani, tane, antane \\
& $\mathrm{PL}$ & ane & tanan \\
\hline
\end{tabular}

Like in Koroshi and Sistani Balochi, deictic shift and an overwhelming predominance of the proximal demonstratives are found in the Vafsi narratives. This can clearly be seen in the tale entitled Moses, the holy hermit and the infidel chieftain (Stilo 2004: 110-115). This is the story in full:

Once his holiness Moses ${ }^{11}$ went to Mt. Sinai and asked, "Oh God, is a merciful infidel ${ }^{12}$ better (lit. 'good')? Or a merciless Muslim?” A voice proclaimed from the heavens, saying, "Of course, a merciful infidel is better than a merciless Muslim. Now go out from this mountain (in $k u$ ) and see for yourself”. When Moses went out off this mountain (in $k u$ ),

11 The phrase hæzræt-e musa 'his holiness Moses' with the honorific hæzræt will be translated as only 'Moses' in the rest of the story.

12 There are two words translated 'infidel' in this story. In the general discussion at the beginning of the story the word kafær is used. Later on in the story the word gæbr is used as well, sometimes in combination with kafær. 
he went up to this top of a mountain (in ku-kællæ) and saw that a holy hermit - he wasn't actually there (andi) himself - had put some bushes under this one's (tini) cooking pot as firewood, and the fire had gone out. Moses said, "Well, since this [fire] under the pot (in zer-dizi) went out, I will light this [fire] under the pot (in zer-dizi). When this holy hermit (in abed) comes back, maybe [he] will give me a little of this lunch of his (in nahares), let me take the trouble to light the fire myself". When Moses came to light this [fire] under the pot (in zer-dizi), the bushes got bumped and everything in the pot spilled out. Just as it spilled out, this holy hermit (in abedæ) came back and said, "Why did you spill the pot out?" [Moses] said, "Honestly, I wanted to make this (in) better, but [it] turned out bad to rekindle the fire under the pot". "No, what business was [it] of yours?" And the hermit threw two or three punches at Moses and Moses threw two or three punches at the hermit, and through an act of the Lord the backs of these (tinan) two stuck together. After the backs of the two had stuck together, as [they] walked along, Moses carried this one (tini) on his back for a while and then the hermit carried Moses for a while. Until [they] arrived, that is to say, to a plain where [they] saw, wow, a hundred tents were pitched. These infidels (in gæbre) $)^{13} \ldots$ [these] were the tents of infidels.

[They] got up to these infidels (in gæbran) - their chieftain himself was 90 years old ... was 100 years old and his wife 90 years old. These (tinan) hadn't had any children. But the Lord had just given these (tinan) a newborn in swaddling clothes. [He] had just given these (tinan) a newborn when these (ine) two arrived and here (indi), so to say, were this one's (tine) guests and this infidel chief (in sær-kærde-ye-gæbri, gæbr-e kafæri) said, "Well, how is it that you have got like this (æzin)?” [They] said, "Well, our story is like this (æzin), it happened like this (æzin). [We] got into a fight and we ended up like this (æzin)". [He] said, "well, you ... is there no cure for this (in)?” [He] said, "Yes, there is a cure". Moses turned and said, "[There is] a cure. But [it] should be an infidel. [He] should be the chief of 100 tents. He should be 100 years old himself. His wife should be 90. [They] should have had no son, but the Lord should just have given that one (tani) a son. [They] should take that son (an lazey) and slit his throat (lit. 'cut his head'), right between the two of us, then we will come apart from one another”. This infidel's (in gæbri) wife had gone to the bathhouse and had put this baby (in zarru) to sleep in the cradle. This infidel (in gæbri) considered it for a bit and said, "Well, I didn't have a child until now. And now, God has willed [it] (lit. 'it pleases God'). Now, let me slit this one's (tini) throat so these (in) can get apart from one another, I don't want this child (in zarru) any more”. This infidel (in gæbr) goes and gets a pen knife and slits his son's throat, right between Moses and the hermit, and these (ine) come apart from one another and start walking away.

[They] start walking away and [he] quietly puts this newborn (in qondaq) back into the cradle and covers his head, but when the wife returns from the bathhouse, this infidel (in gæbr) says, “Oh God, what should [I] say in answer to my wife?” This one (in) starts to beseech the Lord. The wife comes back and says, "Husband, the baby hasn't woken up, has he?” [He] says, “No, [he] hasn't woken up yet. All of a sudden, [he] sees the baby crying. As the baby is crying, the woman comes and picks up the newborn to breast-feed [him] and this infidel (in gæbr) comes over to inspect this newborn's (in qondaqi) throat. The woman asks him, "Husband, what are you looking at so closely?" [He] tells her, "Wife, to tell the truth, [it] happened like this (æzin). I slit this one's (tine) throat and [it] happened like this (æzin). The wife says, "Husband, those two people (an do næfær)

13 The different case forms of the noun gæbr found here are direct singular ( $g æ b r$ ), oblique singular (gæbri), direct plural (gæbre), oblique plural (gæbran) (see Stilo 2004: 223). 
were people of very high standing. Run and bring those ones (tanan) back for a feast”. This one (in) runs, actually goes and brings these ones (tinan) back. [He] says, "[You] are people of very high standing". [He] brings these ones (tinan) back and puts on (lit. 'gives') a feast. When [he] brings these ones (tinan) back, this one (ine) says, "I am Moses”. So this infidel (in gæbr) and the people in the hundred tents all become Muslims. When Moses goes back to Mt. Sinai God asks, "O Moses, is a merciful infidel better? Or a merciless Muslim? [He] answers, "O God, a merciful infidel". And [that] is the end. This (in) is the Vafsi for it.

Deictic shift applies to the whole story, even in the comment at the end "this (in) is the Vafsi for it". In this story, the vast majority of spatial and discourse deictic lexical items thus denote proximal deixis and place the narrator and the audience inside the story. There are only five distal deictic items. The first one, "he wasn't actually there (andi) himself", is an explanatory comment to the audience outside the story. The two following ones, "the Lord should [just] have given that one (tani) a son" and "they should take that son (an lazey) and slit his throat" occur in a description of an imagined situation. The final two deictic devices are "those two people (an do næfær) were people of very high standing. Run and bring those ones (tanan) back for a feast". In this case, distal deixis is in fact used for persons who are far from the deictic center, but it could also fulfill the function of highlighting a climactic statement.

In the three stories The Needle Dirties Himself, The Molla and the Jew, and Shangol, Mangol and Dastegol (Stilo 2004: 49-57) there are no distal deictics whatsoever, except for the adverb ana 'that way' in the expression ena-o ana 'this way and that way' (unit 41, Stilo 2004: 56). There are, however, several instances of a proximal deictic demonstrative being used to denote an entity that is not present at the place where the speaker is, such as in unit 33 (Stilo 2004: 48-50), where the needle says "[I]'ll go tell this mouse (in muši) [and] he'll come make a hole in your bed". The presence of the verbs "to go" and "to come" show that the mouse is not where the needle is, though it is the center of attention within the reported speech.

\subsection{Gorani}

Three texts in the Gawrajūyī dialect of Gorani have been analyzed in this study. Spatial and discourse deictic demonstratives and adverbs in this dialect are presented in tables 9 and 10 (see also Mahmoudveysi et al. 2012: 15, 17).

Table 9: Demonstrative determiners and adverbs in Gorani of Gawraǰū

\begin{tabular}{lll}
\hline & Proximal & Distal \\
\hline Determiner & $\bar{i}$ 'this' & $\bar{a}$ 'that' \\
Adverb & $\bar{i} n \bar{a}, \bar{i} n a h \bar{a}$ 'here' & $\bar{a} n a, \bar{a} n \bar{a}$ 'there' \\
\hline
\end{tabular}


Table 10: Demonstrative pronouns in Gorani of Gawrajū

\begin{tabular}{lll}
\hline Proximal & SG & $\bar{i} n(a), \bar{i} n \bar{\imath}$ \\
& $\mathrm{PL}$ & $\bar{i} n a \bar{n}(a), \bar{n} n(a k) \bar{a} n \bar{\imath}$ \\
Distal & $\mathrm{SG}$ & $\bar{a} n(a), \bar{a} n \bar{\imath}$ \\
& $\mathrm{PL}$ & $\bar{a} n a \bar{n}(a), \bar{a} n \bar{n} n \bar{i}$ \\
\hline
\end{tabular}

The three stories Tìtila and Bībìla ${ }^{14}$ (Mahmoudveysi et al. 2012: 63-77), The Tale of Bizbal (Mahmoudveysi et al. 2012: 81-88), and Mard and Nāmard (Mahmoudveysi et al. 2012: 96-103) will be analyzed here. The text Mard and Nāmard, which contains the largest number of deictics, is presented in full. Parts of the story where there are no deictics are summarized in brackets.

\begin{abstract}
Well, where should [we] begin, where should [we] hear [it], the story of two friends, two men. Both of them go looking for work. [They] are together; their names are Mard and Nāmard. Both of them make a contract together; one says, "Brother". The other says, "Yes?" The first one says, "[We] will go find work to do and a town, a place, where we may earn a morsel of bread for our children, and [we] will come back again together". [They] say, "All right". From home, this one $(\bar{l}(n))$ wraps up bread and [other] victuals and ties [it] to his back. That one ( $\bar{a} n \bar{n})$, simply brings bread and [other] victuals and ties [it] to his back. (They eat and then they fall asleep. Nāmard wakes up first. He takes off with all the foodstuffs. When Mard wakes up, he realises that he has been abandoned.) [He] goes a long way until he reaches the inside of a mill, a machine. [He] goes inside there (āna); [it] is old, nothing anymore, for example, [they] do not work in it anymore. Eh, [he] sits down inside there (āna), [he] hides himself. (A bear, a wolf, and a lion come. $)^{15}$ One of them says, "[Here] is the scent of a human being!" One of them looks around and says, "There is nothing, believe [me], no, [there] is no human being in this place (i dawray)". [They] sit down and - like me now - they tell a story.
\end{abstract}

This one (in) (i.e., the wolf) says, "Brother”. [They] say, "Yes?” [It] says, "The king’s daughter has gone insane. Do [you] know what the cure for her is?" It is this (ina). The wolf speaks. These (innakānī) say, "No". The wolf says, "They tried all kinds of medicine and remedies, but there has not been a cure for her. The dog with the flock, if I only were a human being, [I] would have killed that $\operatorname{dog}(\bar{a} t \bar{u} t a)$ with the flock, [I] would have taken out its brain, [I] would have left it out in the sun, so [it] would have become dry. [I] would have ground [it], [I] would have brought [it], [I] would have steeped [it] like tea, [I] would have given [it] to the king's daughter, so she becomes completely well again". The man says: "Well, this (ina) is the first of the stories. ${ }^{16}$ The wolf says, "As for me, I would eat,

14 The story Titila and Bïbila is a longer version of the same story as Shangol, Mangol and Dastegol in Vafsi, and The tale of Bizbal is also structurally very similar to The needle dirties himself in the Vafsi corpus.

15 The storyteller changes the three animals throughout the story. The bear turns into a leopard, and on one occasion a dog is also mentioned.

16 An alternative translation of ina here and below is 'it is so/thus' (personal communication, Denise Bailey). 
be full with its meat, of the flock". It is not my concern anymore, finally then, that one $(\bar{a} n a)$, that one ( $\bar{a} n a)$ tells another story, thing. The lion answers, he says: "Have you seen this tree (i dāra) outside this mill (az $\bar{\imath}$ bar āsyāw)? [It] has become dry, this (īna) has not brought forth fruit for several years. If only I were a human being, if [I] could find a way for the tree to spread its roots. There were three royal vases in it. [They] are full of gold and precious stones. If only I were a human being, if [I] would have found [it], this tree (ì dāra) too would have then born fruit. This (ina) is the second story. The leopard answers, saying, "Inside the mill, whatever they did, it has not worked. You must find it. There are also two vases in it. If the owner would come for attending this mill (i $\bar{a} s y \bar{a} w a$ ), he would put it to work, it would start to work”. This (ina) is all three stories.

Brother, as for the man, Mard, [he] simply listens until the early morning becomes day. (Then he goes, finds the vases, puts them in a place where he can find them later, finds the flock, kills the dog and takes out its brain.) [He] takes [it] out in that same way ( $\bar{a}$ jür $(a))$ the wolf said, [he] puts it out in the sun, [it] becomes dry, and [he] grinds [it] and puts [it] into his bag. [He] sets off on his way, [he] goes. [He] goes, [he] reaches the city, where [he] sees that, yes this (ina) is [it]. The king whose daughter has become insane is from this city ( $\bar{\imath}$ šăray). Finally, [he] reaches there ( $\bar{a} n \bar{a})$ and says, he goes and knocks on the door of the king's house, and this one (in) (i.e., a person at the door) says, "Who is [it]?" That one (ān) (i.e., another person) says, "Who is [it]?" And [Mard] says, "I have come to cure your daughter, [I] am a doctor". These ones (inān) in turn say, the people in the king's house say, "So many medicines and doctors came and [they] brought remedies, and the doctor gave medicine; his medicine did not bring about healing. (Mard claims to be different and promises to cure the king's daughter within a few days.) The king says, "What is this (ina)?" The servant says, "By God, a young man has come, [he] says, 'I will cure his daughter'. Your highness, what do [you] command?” The king says, "Let [him] come upstairs, no problem, [he] is welcome, this one (in) too, up like those doctors". The king says, "Well, doctor". (Mard introduces himself and asks what he will get if he cures the king's daughter.) The king says, "My daughter, as a gift, [I] will give [her] to you, [I] will also give this crown and throne (i tăj-u taxt) of mine to you". Mard says, "No, may your crown and throne be a gift to yourself. But if [I] cure your daughter, then [I] want your daughter in marriage". The king says, "So be [it], may [she] be a gift to you". So [they] make a contract there (āna). This one (in) (i.e., Mard) also goes, [he] goes a little way to attend to the girl. (He gives her the medicine, trying to remember what the wolf had said.) "After that, for example, then, anoint her back and these (inān) (i.e., some other body parts) with it, put the medicine on it until she is well again". (The girl gets well and is given to Mard in marriage. Then Nāmard turns up.)

Nāmard says, "I recognized you. You are Mard, [you] are indeed Mard, what have [you] done that you reached this [high] position (i pāya)? I wander about in this state (i jüra) without purpose, [I] still have achieved nothing, nothing at all". Mard says, "You are not a good man, [you] have proven yourself. We were friends, you yourself stole the bread and went your way. [You] did not wait right at that moment. I was so hungry, [I] ate earth. You man without a conscience! Nevertheless, now I will also give you this advice ( $\bar{\imath}$ řāwēza), listen! Me, from then on, this God ( $\bar{\imath} x w i y \bar{a})$ had mercy on me, [he] placed this much good (i hamkay xayrša) in front of me (lit. 'my mouth'). Go into the mill, to a corner high up, a leopard and a dog and a lion, [they] come back in the evening, [they] talk. Listen to their stories”. Nāmard says, "Fine!” Brother, this one (īni) goes at once. They have a pipe for the 
stove, Nāmard goes and just sits up on that stovepipe and makes himself very comfortable. In the evening, the wolf and the lion and the leopard return. [They] say, "[Here] is the scent of a human being!” [They] grab Nāmard by his leg, bring him down and tear him to pieces. A bouquet of flowers, a bouquet of narcissus, may I never see your death, never.

The proximal demonstrative determiner is not used as frequently in this text as in the Koroshi Balochi, Sistani Balochi, and Vafsi texts. However, it is still clear that we find deictic shift and that the deictic center is mostly inside the story. The four occurrences of the deictic adverb "there (āna, ānā)", however, seem to break this pattern and move the deixis outside the story. The four occurrences of the distal demonstrative pronoun can be explained as establishing a contrast between Mard and Nāmard, between the first and the second animal who tell their stories, and between the first and the second person at the king's door, while the two occurrences of the distal demonstrative determiner can be explained as indicating spatial and temporal distance. When the wolf tells the story, that $\operatorname{dog}(\bar{a} t \bar{u} t a)$ is not present, and that same way ( $\bar{a}$ jür $(a)$ ) refers back in the discourse to when the wolf had told its story. There is a formal ending to this story as well, but there are no deictic elements in it.

The other two stories Tìtila and Bībila and The Tale of Bizbal contain the following deictic elements (Table 11):

Table 11: Deixis in Titīla and Bībīla and The Tale of Bizbal

\begin{tabular}{lll}
\hline & Proximal & Distal \\
\hline Determiner & 12 & 5 \\
Pronoun & 8 & 3 \\
Adverb & - & - \\
\hline
\end{tabular}

Distal deixis with a determiner is found four times in the expression "the other side" of the river (units 6, 7, 12, Mahmoudveysi et al. 2012: 63-64), thus indicating a contrast to the side of the river where the deictic center is located:

[They] go to the Zimkān [river]; the flock goes to that $(\bar{a})$ [other] side.

A distal demonstrative pronoun is found once in connection with the main protagonists, where they are probably both contrasted with "the flock" and also highlighted (unit 4, Mahmoudveysi et al. 2012: 63):

[They] are at home; the flock goes to the mountains and those (ānān) stay at home.

Another distal demonstrative pronoun (unit 75, Mahmoudveysi et al. 2012: 73) occurs after a dialogue, and refers back to the protagonist who was not the 
last speaker (the wolf), indicating that the wolf remains the current center of attention. Thus, the distal demonstrative creates a contrast between the wolf and the goat:

The goat says, "Morning, at midday [there] will be war. [I] will come to the square and [we] will fight". The wolf says, "All right". That one (ānī) (i.e., the goat) comes, comes to Lālo Pāydar ... (units 73-75, Mahmoudveysi et al. 2012: 73).

However, in another example (unit 40, Mahmoudveysi et al. 2012: 84), the distal demonstrative pronoun does refer back to the last speaker (Auntie Tahmineh). The effect is to direct attention back to the previous speaker (the cat), who is the main character of the story:

So the cat goes and says to the mother of Čiman, the cat says, "Auntie Tahmineh, please send your daughter, [she] should dance for one hour". That one (āni) (i.e., Auntie Tahmineh) says, "Brother, she has no shoes, you must go and make shoes for her". The cat says, "Sure". (units 39-41, Mahmoudveysi et al. 2012: 84)

\section{Temporal deixis in the analyzed corpus}

The main means of anchoring a story in time is the tense form of the verbs. In the following subsections, the use of tense in Koroshi Balochi, Sistani Balochi, Vafsi, and Gorani narratives will be investigated. Interesting observations about temporal adverbs will also be noted.

\subsection{Koroshi Balochi}

In Koroshi Balochi, "the default tense of narration of past events [...] is the nonpast form" (Nourzaei et al. 2015: 20). The introduction of a story, as well as background material in the story, are in the past tense, whereas all the events in the main story line are in the non-past tense. This can be observed in the story Goli and Ahmad, published in Nourzaei et al. (2015: 130-146), which was presented in full in section 3.1 above, as well as in the other stories in the corpus. The verb forms at the beginning of Goli and Ahmad are presented below as they are in the original text. (Note that the translation of the verb forms was somewhat modified in section 3.1 to give a more idiomatic translation into English.) Verb forms in direct speech have not been analyzed, since they are not part of the story line. In fact, it could be argued that verbs in subordinate nominal clauses after verbs of perception are not part of the story line either, but they have been included in the analysis because they exhibit an interesting variation in tense 
use. The same pattern as in this extract is found in all the tales in Koroshi Balochi. ${ }^{17}$

Well, once upon a time (lit. 'Well, there was $[a d]$ one, there was [nayad] no one, except for God, there was [nayad] no one') well, a woman, there has been (boda) a woman, her name has been (boda) Goli. Actually she has been (boda) very bad. Actually she has been (boda) very bad. She has been troubling her husband (azzīyate šūay makanā boda), you know.

So, one day her husband says (aši), "Hey, Goli, all these people are going to pick green herbs here and there, come on $(b y \bar{a})$, let the two of us go, too". She says (aši) , "Very well, let's go". They go (arran) out into this wilderness, you know, they have been picking ( $m a$ čenēn boda) green herbs, like this. The man goes (arra) and finds (pēda akant) a well. The man finds (pēdā akant) a well. He says (ašĩ), "Hey, my wife, look into this well, what is this thing that shines?” The woman comes (akay), sir, to look (say kan) into the well. The man pushes her (lohe adā) in such a way that she goes (arra) into the well.

She goes (arra) into the well and he comes (akay) back home. After four, five days her husband says (ašit), "I shouldn’t have done like this, I shouldn't have thrown her into the well. She was my wife". Anyhow, he becomes $(a b \bar{i})$ troubled, takes $(a z o)$ a rope and goes (arra). He takes (azo) it and goes (arra) until he arrives (arasī) at the well. He throws (aprēnī) the rope into the well and says (ašì), "Hey, Goli, if you are alive, take hold of the rope, so that I can pull you up". Well, he pulls (akaši) up the rope, like this. He sees (agenni) the rope is (en) heavy.

He pulls (akašì) and pulls (akašid) until suddenly he sees (agennīt) that a dragon came $(\bar{a} k)$ up. A dragon came $(\bar{a} k)$ up. He becomes $(a b \bar{l})$ panicky to let go (wel dā) of the rope, but the dragon says $(a s ̌ \bar{l})$, "Don’t let go of the rope, I will give you whatever you want". The man says $(a \bar{s} \bar{l})$, "Fine, can you get the king's daughter for me?" The dragon says (aši) , "Yes, I will get her for you”. Then the dragon says (ašì), "Very well, tonight I will go and wrap myself around the neck of the king's daughter. Then, whoever came, I will not unwrap myself except for you. When you came, I will unwrap myself. Then say, 'Oh king, if you marry off your daughter, give her to me, so that I may open up this dragon'”. Well, in the evening the dragon goes ( $a r r a)$ and wraps (apēči) itself around the neck of the king's daughter.

All the verbs in the story line are in the non-past tense. The only verbs found in the past tense are those that introduce the story in the first paragraph, and those that describe background imperfective (ongoing) events (they have been picking (mačenēn boda) green herbs). Once there is also a verb in the past tense in the subordinate nominal clause after a verb of perception (he sees (agennit) that a dragon came ( $\bar{a} k)$; i.e., 'had come'). In another nominal clause, however, the non-past is used (he sees (agennī) the rope is (en) heavy).

17 Subject pronouns and other words that have been supplied for syntactic reasons or for the sake of better comprehension are not marked in this section, since the discussion here concerns the verbs. 
For tense forms of the verbs, we thus have a deictic shift in Koroshi Balochi and the tense is anchored in the very story, which is portrayed as ongoing at the very moment by means of using the non-past tense. There are, however, three time adverbials in the corpus that modify this picture slightly, since they all contain a distal demonstrative determiner: that day ( $\bar{a}$ rōc̆) (unit 18, Nourzaei et al. 2015: 168), that day ( $\bar{a} r \bar{o}$ ) (unit 68, Nourzaei et al. 2015: 185), and that hour (ā sāhat) (unit 100, Nourzaei et al. 2015: 196).

\subsection{Sistani Balochi}

The picture that emerges for Sistani Balochi is somewhat different. Here all the verb forms are in the past tense and therefore the story is temporally anchored at the time of narration rather than within the story itself. All verb forms in the narrative parts of the story (direct speech excluded), which is the same story as that in section 3.2, are given below. Only the evidential marker gušit at the very beginning of the story is in the non-past tense, which is logical, since it refers to a non-past event (Barjasteh Delforooz 2010: 378-383). All the other verb forms are in the past tense.

Sir, they say (lit. 'he says') (gušit), there were (atant) three cows. All these three cows were (atant) in unity (lit. 'in one heart'), there was (at) a black one, there was (at) a light brown one, and there was (at) a white one. These were (atant) in unity from that old time. Wherever they grazed (čartant) no beast of prey had (nadāšt) any power over them. If there was (būtēn) a lion, if there was (būtēn) a leopard, if there was (būtēn) a wolf, that attacked (alma kurtēn) one of them, all three attacked (amlaa kurtant) it and no beast of prey attacked (lit. 'went on') (našut) them, because they were (atant) of one hear and of one mind. What did a certain lion do (kurt)? It was $(b \bar{u} t)$ stalking them, it was $(b \bar{u} t)$ lying in ambush for them. It said (guštī), “Unless I change the mind of each one of them, I won't be able to eat them". This lion came ( $\bar{a} t)$ and lied (drōg jat) to them, told them a lie (drōge jat), "O fellows, you are such good friends, I am your fourth brother. I have seen a pasture in a place. It is very green (lit. 'spring'). You ... let's go there, I will take you there, you eat that grass, I will watch over you”, the lion said (gušt). It deceived (lit. 'made donkey') (xarē kurt) them and took (burt) them. When it took (burtē) them there, it said (guštī), "Now I will watch over you on this mound, you eat this grass". It passed (būt), that day passed (būt) and the next day passed (būt), it whispered (lit. 'entered') (putrit) in the light brown cow's ear and in that of the white one. It said (guštī), "O friend, your hair and my hair are the same colour, that black one is ill-matched (lit. 'unripe') among us. You, don't help it, I will eat it, a lot of grass will remain for you". It confused (lit. 'ruined') (xarābē kurt) their minds and one of the cows said (guštī), "Fine". So it seized (čalāpt) the black one. They (i.e., the other cows) didn't help (kumak nakurtant). When they didn't help (kumak nakurtant), it overpowered (lit. 'was strong') (zōr at) this single one. It ate (wārtēe) this one up. When it ate (wārt) and finished it (alāsē ku) ..., when it finished it (alāsē ku), it whispered (lit. 'sneaked') (putrit) in the light brown cow's ear and said 
(gušti)), "Your hair and mine are the same colour, you, don't help it, when I eat this white one, all the grass will remain for you. Then I will watch over you here, you can eat!" It said (gušti ), "Fine". When it seized (gipt) this one too, that one (i.e., the light brown one) didn't help (komak nakurt). The lion ate (wārt) this one (i.e., the white one) too. When it finished it (alāse kurt) this one too, it said ( $g u$ ) to that one, "Now I alone am more powerful than you". It ate (wārt) that one too. In this manner, with this trick, it destroyed (ziyāne kurt) them.

When it comes to time adverbials, unlike tense, they sometimes demonstrate proximal deixis, i.e., anchoring in the story (deictic shift). There are a number of instances of proximal time deictics in the corpus, such as the demonstrative deictics in unit 114 (Barjasteh Delforooz 2010: 343, units 113-119 are translated below) and unit 15b (Barjasteh Delforooz 2010: 358), which refer to time rather than to space:

From the first day when this girl had been born, until this very [time] ( $a m \bar{e})$ when she was mature and had reached puberty, except for her mother and father who knew that this was a girl, even the neighbours didn't know that this was a girl.

... the Baloch nomad, at this moment (lit. 'here') (idā) (i.e., at the moment when his camel was dying), experienced the feeling of desperation....

Also the time adverbials "today, tomorrow, and the day after tomorrow" are used in these texts in narrative parts to refer to "the same day, the next day, the day after the next” (unit 10, Barjasteh Delforooz 2010: 343; units 42-43, Barjasteh Delforooz 2010: 380; unit 28, Barjasteh Delforooz 2010: 385; unit 50, Barjasteh Delforooz 2010: 387). Units 41-44 (Barjasteh Delforooz 2010: 380-381) read as follows:

It passed, that day (lit. 'today') (mrōčì) passed and the next day (lit. 'tomorrow') (bāndā) passed, it whispered in the light brown cow's ear and in that of the white one.

Another passage that would indicate temporal anchoring in the actual narration is units 72-73 (Barjasteh Delforooz 2010: 299) where the word šapi is translated "tonight". However, in view of the fact that a parallel adverb sōbi has been translated "in the morning" (unit 119, Barjasteh Delforooz 2010: 374; unit 72, Barjasteh Delforooz 2010: 388), it seems likely that šapi can also be translated as "at night"18: "Surely I will die tonight (or 'at night') (šapi). Death did not come to him tonight (or 'at night') (̌̌api)...”.

18 This translation, or the translation 'this night' was also suggested by one of my Baloch friends. 


\subsection{Vafsi}

The verb forms in Vafsi exhibit yet another pattern. Most stories start out in the past tense, not only for the initial background description, but also for foreground events in the event line at the beginning of the story. In Tale B7 (Stilo 2004: 110-113), given in full above, there is one tense shift to the non-past tense, which takes place between units 24 and $27 .{ }^{19}$ In Tale A1 (: 26-29), Tale A3 (Stilo 2004: 32-47), Tale A4 (Stilo 2004: 48-51), Tale A9 (Stilo 2004: 104-109), and Tale B8 (Stilo 2004: 116-123), there are several shifts between past and non-past tense. All the tales start out in the past and end in the non-past tense, except for A1, which ends in the past tense. Tale A5 (Stilo 2004: 52-53) is in the past tense from the beginning until the end. This is also true for Tale A6 (Stilo 2004: 54-57). The point where tense shift in Tale B7 occurs is presented here:

The infidel considered (molazæs bækærde) it for a bit and said (va), "Well, I didn't have a child until now. And now, God has willed it (lit. 'it pleases God'). Now, let me slit his throat so they can get apart from one another, I don't want this child any more”. This infidel goes (ætari) and gets (ærgiri) a pen knife and slits (ærbirine) his son's throat, right between Moses and the hermit, and they come apart (joda -rbuænd) from one another and start going (bæna -rkærende siæn).

In Vafsi, the same word is used for 'tomorrow' and 'the next day' (soæy) (Stilo 2004: 277). In Text A5 (unit 9, Stilo 2004: 52), a proximal demonstrative determiner is even added before soæy. An enclitic pronoun $(=s)$ is added to the phrase soæy šo 'tomorrow night' to denote 'the next night' (unit 91, Stilo 2004: 40):

The next day (lit. 'this tomorrow') (in soæy) the Jew came ...

Then it turned into the next night (lit. 'it’s tomorrow night') (soæy šos). On the next night (lit. 'it's tomorrow night') (soæy šos), this vizier got up again.

It is also interesting to note the proximal demonstrative determiner in the temporal expression "at first" in Tale A9 (unit 31, Stilo 2004: 106):

At first (lit. 'this first') (in ævvæl) they said no.

\subsection{Gorani}

In the three Gorani tales, when direct speech is excluded, the verbs are almost invariably in the non-past tense both in the introduction and in the event line. One or two past tense verb forms are, however, used for background informa-

19 Units 25-26 are direct speech. 
tion, e.g., in a subordinate adverbial clause (unit 13, Mahmoudveysi et al. 2012: 64 ) and in a relative clause (unit 64, Mahmoudveysi et al. 2012: 100). Units 2-8 of the tale Tìtila and Bībìla (Mahmoudveysi et al. 2012: 63-64), where both the introduction and verbs in the event line are found, read like this:

\begin{abstract}
Tìtila and Bībila, in the Kurdish language we say (mwāžām), "The lame goat and the lame ram". There is $(\mathrm{mawu})$ a goat and there is $(\operatorname{maw}(u))$ a ram; they are (mawin) lame. They are (mawin) at home; the flock goes (mašu) to the mountains and they (i.e., the goat and the ram) stay (mamanin) at home. They ... The front of the gate is (mawu) open; they go (marawin) out of the courtyard and they say, "Let's go, let's reach the flock". They go (mašin) to the Zimkān river; the flock goes (mašu) to that other side. From the side of the Zimkān river, the flock crosses (lit. 'does') (makari) to that other side. The flock crosses (lit. 'does') (makari) to that side.... Suddenly they (i.e., the goat and the ram) say ( $m w \bar{a} n)$, "Hey, brother!” The ram says (mwāy), "Yes?”
\end{abstract}

When it comes to time adverbials, Mahmoudveysi et al. (2012: 81 n. 43) note that the difference between "that/this evening" and "the following evening/night" is išaw versus $\bar{\imath} \check{s} a w$. What is relevant to this discussion is that according to this definition, there is no difference between "that evening" and "this evening". It is also interesting to note that the phrase "the following evening/night" contains the proximal demonstrative determiner $(\bar{l})$.

\title{
5 Summary and comparison with other Iranian languages
}

The four linguistic variants in this study show interesting variation when it comes to deictic shift (see Table 12). First of all, it is more common for spatial deixis to be shifted to the story than for tense to be anchored in the story. Koroshi Balochi, Sistani Balochi, and Vafsi present almost total spatial deictic shift, whereas in Gorani there are a few cases of the deictic adverb 'there (āna, $\bar{a} n \bar{a})^{\prime}$, which move the deixis outside the story. It also seems that proximal deixis is the norm in at least Koroshi Balochi, Sistani Balochi, and Vafsi to repeatedly mark the current center of attention with deictics. ${ }^{20}$

Gorani is the language that has the strongest tense anchoring inside the narrative, with almost exclusive use of the non-past tense. At the other extreme

20 Thomas Jügel (personal communication) also notes the same phenomenon in German, and comments that distal pronouns are rarely used, their function being taken over by proximal pronouns and elements that are neutral with respect to deixis. 
we find Sistani Balochi, which has no tense anchoring in the narrative (only past tense verb forms), but does have some adverbials that move the deictic center into the story. Vafsi is ambivalent, with constant shifts between the past and non-past tenses. Normally the tales start out in the past tense and end in the non-past tense. As for Koroshi Balochi, tense use is consistent with background material in the past tense and foreground material in the event line in the nonpast tense. On the other hand, there are a few temporal adverbials with distal demonstrative determiners in Koroshi Balochi.

Table 12: Summary of spatial and temporal deixis in the four variants under study

\begin{tabular}{lll}
\hline Language & $\begin{array}{l}\text { Spatial deixis } \\
\text { inside narrative }\end{array}$ & $\begin{array}{l}\text { Tense anchoring } \\
\text { inside narrative }\end{array}$ \\
\hline Koroshi Balochi & + & + \\
Sistani Balochi & + & - \\
Vafsi & + & $+/-$ \\
Gorani & $+/-$ & + \\
\hline
\end{tabular}

Studying deixis in Persian, Roberts (2009: 233) argues for “a bias or preference for proximal deixis over distal deixis”. Persian prefers, as an example, to use the proximal deictics 'now, here, this, yesterday, today, tomorrow etc., both with the speech moment as the deictic center (he will come tomorrow) and with another deictic center than the speech moment (he told me that he would come the next day (lit. 'tomorrow') (Roberts 2009: 235-241). Further studies are needed to determine to what extent the preference for proximal deixis in Persian should be attributed to deictic shift in this language.

Deictic shift has also been reported for Talyshi folktales by Paul (2011: 93), who shows that the deictic center sometimes "is projected onto the narrative's chief protagonists" and sometimes "onto the central locational reference point" of a certain episode in the narrative. Barjasteh Delforooz (2010:146) reports the same phenomenon for Sistani Balochi. He finds that the spatial deictic center in the stories he analyzes in depth is normally where the main participant of the story is located, but that the deictic center sometimes moves ahead of the major participant to the scene where an important event or the climax of the story will take place. The point is that it stays inside the story, which means that we are dealing with deictic shift. Barjasteh Delforooz concludes that in his data, proximal deixis "is much more frequent than distal deixis" and that in fact it is even more frequent in Sistani Balochi than in Persian (Barjasteh Delforooz 2010: 159).

21 Here only the verbs in the event line are considered. 
The distal demonstratives are mainly used for establishing a contrast between two different entities, for highlighting purposes, and for reactivation. The use of a distal demonstrative pronoun to establish contrast is also noted in Kumzari by Wal Anonby (2015: 67), who finds that "a secondary participant is referenced by the pronoun $\bar{a} n$ [...] in place of third person singular $y \bar{e}$, to distinguish it from a primary participant”.

Other features of the stories under study also contribute to the deictic shift of the listener from the present world to the world of the narrative. One of these is the total predominance of direct speech. Now and then skillful narrators also address the audience with phrases such as "listen brothers" (Barjasteh Delforooz 2010: 303, unit 1), “sir” (Nourzaei et al. 2015: 123, unit 2), or an even more personal address such as "dear doctor", as found in Barjasteh Delforooz (2010: 391, unit 115).

It is thus clear that there are numerous devices to make the oral narration lively and exciting by bringing the distant near, thereby giving the audience a fascinating experience of journeying to "a time and a land that is not". 22

\section{Acknowledgments}

Sincere thanks to Denise Bailey, Thomas Jügel, Stephen H. Levinsohn, and an anonymous reviewer for useful comments on earlier versions of this article. All remaining errors and shortcomings are, of course, my own.

\section{References}

Anderson, Stephen R. \& Edward Keenan. 1985. Deixis. In Timothy Shopen (ed.), Language typology and syntactic description, vol. III: 259-308. Cambridge: Cambridge University Press.

Barjasteh Delforooz, Behrooz. 2010. Discourse features in Balochi of Sistan. Oral narratives [Studia Iranica Upsaliensia 15]. Revised version. Uppsala: Acta Universitatis Upsaliensis. http://uu.diva-portal.org/smash/record.jsf?pid=diva2:345413 (accessed 10 December 2015). Diessel, Holger. 1999. Demonstratives. Form, function, and grammaticalization. Amsterdam and Philadelphia: John Benjamins.

Fillmore, Charles J. 1997. Lectures on deixis. Stanford, CA: CSLI Publications.

Haig, Geoffrey L. J. 2008. Alignment change in Iranian languages. A constructional grammar approach. Berlin \& New York: Mouton de Gruyter.

22 See www.poemhunter.com/poem/the-land-that-is-not/ for a poem with the English title The Land That Is Not, originally written in Swedish by the poet Edith Södergran. 
Jahani, Carina \& Agnes Korn. 2009. Balochi. In Gernot Windfuhr (ed.), The Iranian languages, 634-692. London \& New York: Routledge.

Korn, Agnes. 2005. Towards a historical grammar of Balochi [Beiträge zur Iranistik, 26]. Wiesbaden: Reichert.

Levinsohn, Stephen H. 2015. Self-instruction materials on narrative discourse analysis. SIL International. http://www-01.sil.org/ levinsohns/narr.pdf (accessed 23 November 2015).

Lyons, John. 1977. Semantics. Vol. 2. Cambridge: Cambridge University Press.

Mahmoudveysi, Parvin, Denise Bailey, Ludwig Paul \& Geoffrey Haig. 2012. The Gorani language of Gawrajū, a village of west Iran [Beiträge zur Iranistik, 35]. Wiesbaden: Reichert.

Nourzaei, Maryam, Carina Jahani, Erik Anonby \& Abbas Ali Ahangar. 2015. Koroshi. A corpusbased grammatical description [Studia Iranica Upsaliensia, 13]. Uppsala: Acta Universitatis Upsaliensis. http://uu.diva-portal.org/smash/record.jsf?pid=diva2\%3A810250 (accessed 10 January 2016).

Nyberg, H. S. 2004. Muntlig tradition, skriftlig fixering och författarskap. Compiled and edited by Bo Utas. Uppsala: Kungl. Humanistiska Vetenskaps-Samfundet i Uppsala.

Ong, Walter. 1982. Orality and literacy. The technologization of the word. London \& New York: Methuen.

Paul, Daniel. 2011. A glance at the deixis of nominal demonstratives in Iranian Taleshi. In Agnes Korn, Geoffrey Haig, Simin Karimi \& Pollet Samvelian (eds.), Topics in Iranian linguistics, 89-102 [Beiträge zur Iranistik, 34]. Wiesbaden: Reichert.

Paul, Ludwig. 2003. The position of Balochi among western Iranian languages: The verbal system. In Carina Jahani \& Agnes Korn (eds.), The Baloch and their neighbours: Ethnic and linguistic contact in Balochistan in historical and modern times, 61-71. Wiesbaden: Reichert.

Roberts, John R. 2009. A study of Persian discourse structure [Studia Iranica Upsaliensia, 12]. Uppsala: Acta Universitatis Upsaliensis. http://www.diva-portal.org/smash/record. jsf?pid=diva2\%3A285628 (accessed 28 October 2015).

Segal, Erwin M. 1995. A cognitive-phenomenological theory of fictional narrative. In Judith F. Duchan, Gail A. Bruder \& Lynne E. Hewitt (eds.), Deixis in narrative: A cognitive science perspective, 61-78. Hillsdale, NJ, \& Hove, UK: Lawrence Erlbaum Associates.

Stilo, Donald L. 2004. Vafsi folk tales. Supplied with folklorist notes and edited by Ulrich Marzolph [Beiträge zur Iranistik, 25]. Wiesbaden: Reichert.

Utas, Bo. 2008. Manuscript, text and literature. Collected essays on Middle and New Persian texts. [Beiträge zur Iranistik, 29]. Edited by Carina Jahani and Dariush Kargar. Wiesbaden: Reichert.

Wal Anonby, Christina van der. 2015. A grammar of Kuzmari. A mixed Perso-Arabian language of Oman. Leiden: Leiden University dissertation.

Zubin, David A. \& Lynne E. Hewitt. 1995. The deictic center: A theory of deixis in narrative. In Judith F. Duchan, Gail A. Bruder \& Lynne E. Hewitt (eds.), Deixis in narrative: A cognitive science perspective, 129-155. Hillsdale, NJ, \& Hove, UK: Lawrence Erlbaum Associates. 